\title{
Using an easy and fast modified chemical method for detection of methanol content in drinking herbal distillates
}

\begin{abstract}
Methanol is an essential compound in land plant physiology. Drinking of it can cause poisoning that the most common symptom of it is permanent blindness. A new modified chemical method is needed for detection of methanol in herbal distillates, because all of sophisticated methods for direct determination of methanol require advanced instruments and high technical knowledge which preparing them is very expensive. In this study, a chemical method was modified for detection of methanol content in herbal distillates.

For detection and semi determination of methanol level in herbal distillates by the proposed method, 30 different herbal distillate samples were considered. Briefly, $50 \mu \mathrm{L}$ of sulfuric acid and the same amount of potassium permanganate solutions are added into $0.5 \mathrm{~mL}$ of a $1: 1$ ratio water diluted sample. After 5 min, examination was continued with adding $50 \mu \mathrm{L}$ of sodium hydrogen sulfite solution, chromotropic acid and $1 \mathrm{~mL}$ concentrated sulfuric acid, respectively. The appearance of purple color with each intensity would be deduced as positive outcome and the eye comparison of its intensity with color standards is lead to attain semi determined results. The obtained results by the chemical method are confirmed via GC method. According to the results, the presence of methanol in all of examined samples was confirmed.

The proposed chemical method is an easy method with suitable sensitivity and accuracy for detection and semi determination of methanol content in herbal distillates and hence, it can be useful to prevention of methanol chronic poisoning by methanol quality control of methanol in these products in mentioned cases.
\end{abstract}

Keywords: methanol poisoning, methanol, herbaceous distillates, gas chromatography
Volume 6 Issue 2 - 2017

\author{
Maryam Nasouri Gazani, Shahab Shariati,Ali \\ Rafizadeh \\ Department of Chemistry, Rasht Branch, Islamic Azad University, \\ Iran
}

Correspondence: Shahab Shariati, Department of Chemistry, Rasht Branch, Islamic Azad University, Rasht, Iran, Email shariaty@iaurasht.ac.ir

Received: August 05, 2017 | Published: September 22, 2017

\section{Introduction}

Methanol is one of the most popular organic solvents that have extensive applications in industries and household usages. ${ }^{1}$ There are different amounts of methanol in all alcoholic and some non -alcoholic drinks (such as herbal distillates). ${ }^{2,3}$ Methanol is produced and stored as a carbon reserve in all land plants tissues liquid pools, especially green stems and leaves in all life duration..$^{4-9}$ Concerning the metabolism related methanol release, Frenkel et al. ${ }^{10}$ found that methanol within the leaf is mostly produced as a consequence of the demethylation of the pectin matrix, a necessary step in the extension of the cell walls during plant growth. ${ }^{10}$ On the basis of the pectin content, Galbally et al. ${ }^{11}$ distinguished between two major cell wall types with a high or low potential for methanol release. ${ }^{11}$ Most other plants have cell walls with a higher potential of methanol release. To a minor extent, methanol can be the result of an enzymatic cleavage of lignin, demethylation of DNA and protein repair pathways. ${ }^{10,11}$ So, existence of it in herbaceous distillates is due to biological activities of plant in its life time, because, absence of permanent and sufficient carbon reservoirs for land plants in different seasons of year and dependence on photosynthesis process to environmental conditions are caused, they produce and store methanol as a carbon reserve in their all tissues liquid pools due to its high solubility, especially green stems and leaves in all life duration. ${ }^{4-6}$ Also, kinds of stresses like hypoxia, frost and high ozone concentrations, senescing, injuring (e.g. herbivore attacks, cutting), drying of leaves and even plant's aging can increase the methanol production in plant..$^{7-9,12-15}$ Based on it, several authors reported methanol emission to atmosphere as part of the plant metabolism particularly during growth. ${ }^{16-20}$
Furthermore, methanol plays several roles in plant physiology and signaling, in plant-herbivore relationships and in defensing against micro-organisms. Therefore, presence of methanol in juices, herbal distillates and the other plant products is completely logical, as, according to American Standard, existence of $120-460 \mathrm{mg} \mathrm{L}^{-1}$ (with mean $140 \mathrm{mg} \mathrm{L}^{-1}$ ) methanol in fresh and canned juices (such as orange and grape fruits) is permitted. ${ }^{21}$ So, unknown drinking of large amount of methanol by juices, herbal distillates and the other extracts of plants can cause chronic methanol poisoning.

Also, in addition of high content of methanol in land plants tissues, as for existence high amounts of Pectic substances in plants tissues in the presence of pectolytic enzymes and releasing methanol after pickup them for preparation of distillates, huge amounts of methanol can concentrate in final product. Therefore, Herbal distillates is usually a colorless liquid consisting mainly of water and also numbers of very different organic compounds such as diverse drug compounds and essences which among them methanol is also found as a unwanted chemical. Because, Fermentation process need to some favoring conditions such as long time duration (about 30-40 days), optimized temperature (about $20-30^{\circ} \mathrm{C}$ ) and anaerobe media for complication that no one of them is not prepare in herbal distillates distillation process. So, in spite of current idea, existence of methanol in herbaceous distillates is not related to fermentation of cellulose and the comparison of simultaneously break down of pectin leading to methanol production in fermentation process of beverages preparation process is caused this mistake believe.

Methanol is highly toxic to human and accidental intake of enough amounts of this alcohol causes severe intoxication. Generally, the 
sever type of methanol poisoning is very dangerous for different organs such as central nervous system, kidney, eyes and etc. that permanent blindness is the most common symptom of it in acute conditions. ${ }^{22}$ Because, following acute methanol intoxication a severe metabolic acidosis can occur due to oxidizing of methanol to formaldehyde and formic acid by liver alcohol and formaldehyde dehydrogenase enzymes respectively and the accumulation of formaldehyde and formic acid, especially formic acid. ${ }^{23,24}$ Formate is an inhibitor of mitochondrial cytochrome $\mathrm{C}$ oxidase which causes histotoxic hypoxia. This leads to reduced adenosine triphosphate (ATP) production. The optic nerve is especially sensitive to reduced ATP production..$^{23}$ For this reason, visual changes with progression to blindness is the most important symptom of methanol poisoning. Because, the first clinical features may mimic the signs and symptoms of other diseases. ${ }^{25}$ Generally, many various signs present in different steps of methanol toxicity (respiratory distress, gastrointestinal discomforts, headache, dizziness, nausea, vomiting, neurotoxicity, multi-organ-system failure, cardiovascular instability, coma, seizure, gastrointestinal and putaminal haemorrhage, infarction, pancreatitis and death). ${ }^{26-32}$ Delayed diagnosis and treatment are the main reasons to gain poor outcomes. ${ }^{33,34}$ So, many patients may die outside of hospital before diagnosis of methanol poisoning. But, in spite of sever conditions, In chronic type of methanol poisoning, slow intake of methanol during a long time (about 6 mounts) is lead to sluggish increasing of methanol metabolites in body and because of high sensitivity of optic nerve to reduction of ATP production, perhaps, this nerve is only damaged tissue and so, blurred vision leading to blindness is only visible symptom in this type of the intoxication. This type of methanol poisoning has recently reported by some physicians in Iran that motivated the Iran contra's health official's anxieties. ${ }^{35-37}$

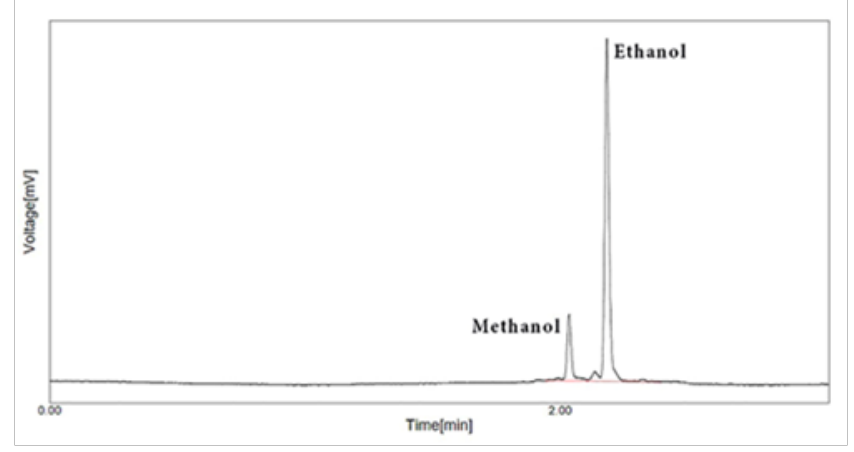

Figure I GC chromatogram of methanol and ethanol in a standard sample.

Presently, methods based on HPLC, ${ }^{38}$ GC, ${ }^{39}$ selective flowinjection, ${ }^{40}$ enzymatic method, ${ }^{41}$ FT-IR ${ }^{42}$ and $\mathrm{GC}-\mathrm{MS}^{43}$ are used to quantitative determination of methanol content in various samples. Analysis of the samples with HPLC, GC or GC-MS needs very expensive apparatus ${ }^{38}$ and high experience. Also, the other mentioned methods cannot be used for the direct determination of methanol and need especial preparation of samples. Therefore, these problems make all of them difficult and troublesome or inapplicable in common laboratories. ${ }^{38}$ On the other hand, there are some other different methods $^{43-47}$ for determining formaldehyde in various samples which one of them is Chromotropic Acid (CA) method that was recommended by the National Institute for Occupational Safety and Health (NIOSH) ${ }^{36}$ Also, it can be utilized for indirect determination of methanol after its oxidation to formaldehyde, ${ }^{42,48}$ as, it has been recommended as an official method by AOAC (Association of Official Analytical Chemists) for this purpose ${ }^{49}$ But, this old chemical method has some application issues. For example, it requires long operation time and has a painstaking process, ${ }^{50}$ but, the major drawback of it is the consumption of large volume of hot concentrated sulfuric acid which is potentially hazardous and corrosive.$^{48}$ On the other hand, this method is only recommended by AOAC for measuring of methanol in alcoholic drinks and therefore, application of it in non -alcoholic ones (such as herbal distillates) can be lead to false results. Therefore, due to the huge production and consuming of herbal distillates, to have an easy technique based on CA method for qualitative detection and semi determination of methanol in such products can be useful for decreasing chronic methanol poisoning rate. So, the aim of this study is to investigate a modified qualitative CA method for detection of methanol in herbal distillates.

\section{Materials and methods}

In this study, the methanol content of 30 herbal distillates was examined by two chemical and instrumental (GC) methods. Finally, all of results were analyzed using SPSS ver. 20.

\section{Instrumentation}

A GC instrument from Yanglin company (YL 6100 GC, South Korea) with FID detector and equipped with a Tr25 column $(30 \mathrm{~m} \times$ $0.53 \mathrm{~mm}$ ) was used to measure methanol content of each sample.

\section{Chemicals}

The needed sulfuric acid, sodium hydrogen sulfite, potassium permanganate, chromotropic acid, methanol and ethanol for preparation of standard solutions were purchased with analytical grade from Merck and Aldrich companies. Also, 30 different herbal distillates (with names of Mentha Spicata L., Foeniculum vulgare L., Alhagi maurorum L., Anethum graveolens L., Cichorium intybus L., Salix aegyptica L., Citrus aurantium L., Fumaria officinalis L., Rosa damascena L.andTrigonella foenum-graecum $L$.) made by three industrial companies as samples were purchased from different stores. Manufacturing and expiring dates of each company products were nearly close together and maximum about one month alteration, whereas, this difference was nearly 1-4 months in all different companies' samples.

\section{Preparation of Reactants}

Potassium permanganate $\left(0.1 \mathrm{~mol} \mathrm{~L}^{-1}\right)$, sodium hydrogen sulfide solution $\left(0.15 \mathrm{~mol} \mathrm{~L}^{-1}\right)$ and chromotropic acid disodium salt solution $\left(0.05 \mathrm{~mol} \mathrm{~L}^{-1}\right)$ were prepared in three separated $100 \mathrm{~mL}$ flask by dissolving $1.58,1.56$ and $2.0 \mathrm{~g}$ of each of them in distilled water, respectively. Also, a $0.5 \mathrm{~mol} \mathrm{~L}^{-1}$ of sulfuric acid solution was prepared by adding $2.65 \mathrm{~mL}$ sulfuric acid ( $>98 \%$ ) into a $100 \mathrm{~mL}$ flask and diluted with distilled water to $100 \mathrm{~mL}$. Furthermore, $1.0 \mathrm{~mL}$ of concentrated $(98 \%)$ sulfuric acid $\left(18.4 \mathrm{~mol} \mathrm{~L}^{-1}\right)$ was used in the end step of test.

\section{Standard solutions}

To perform GC analysis, $126 \mu \mathrm{L}$ of each of methanol and ethanol were separately mixed into two $10 \mathrm{~mL}$ flasks with distilled water for preparation of $10000 \mathrm{mg} \mathrm{L}^{-1}$ concentration of them. Then, two series of standard solutions containing $6.25,12.5,25,50$ and $100 \mathrm{mg} \mathrm{L}^{-1}$ of methanol with ethanol as internal standard (by adding $100 \mu \mathrm{L}$ of mentioned prepared ethanol solution) and 25, 50, 100 and 200mg $\mathrm{L}^{-1}$ of methanol without ethanol were prepared (by serial method) in distilled water for using in both GC and proposed chemical methods, respectively.

\section{Samples}

Also, for preparing of samples to measure by two GC and proposed chemical methods, $100 \mu \mathrm{L}$ of $10000 \mathrm{mg} \mathrm{L}^{-1}$ aqueous ethanol solution 
was added into $10 \mathrm{~mL}$ of each sample as internal standard and for another one, one volume of each sample (triplicate) was diluted with equal volume of distilled water (a 1:1 ratio) with 1:2 concentration ratio to examine as double.

\section{Procedure of chemical method}

To perform tests, $0.5 \mathrm{~mL}$ of standards and dilutions of samples were poured into separated test tubes with addition of $50 \mu \mathrm{L}$ of sulfuric acid and potassium permanganate solutions. After 5 minutes, examination was continued with adding $50 \mu \mathrm{L}$ of sodium hydrogen sulfite solution and hard shaking for full decoloring mixture. Then, $50 \mu \mathrm{L}$ of chromotropic acid solution and $1 \mathrm{~mL}$ of concentrated sulfuric acid were added to test tubes, respectively and shook well. After five minutes for completion of reaction, the results deduce as below:

The remained colorless of mixture would be concluded as negative result, whereas, appearance of purple with each intensity would be deduced as positive outcome. After that, the obtained positive color was compared with color standards test tubes for defining of estimated methanol content of each sample. Then, the obtained data for methanol content of samples was multiply in dilution factor (2) for final computation of results. It is necessary to be mentioned that for assuredness attained results, each sample was dilutes three times and each of them was examined twice.

\section{Procedure of GC method}

All prepared standards and samples were directly injected $(2 \mu \mathrm{L})$ to $\mathrm{GC}$ system. The column temperature was set at $50^{\circ} \mathrm{C}$ (for $1 \mathrm{~min}$ ) and then increased with $10^{\circ} \mathrm{C} / \mathrm{min}$ ramp to $80^{\circ} \mathrm{C}$. He (at $26 \mathrm{~mm} \mathrm{~min}-1$ rate) was used as carrier gas for separations. All of samples were injected to GC for three times and then, their averages were used to calculate the results using internal standard.

\section{Results}

In order to obtain correct results in GC method, all samples and standard solutions (6.25 to $100 \mathrm{mg} \mathrm{L}^{-1}$ ) mixed with $100 \mathrm{mg} \mathrm{L}^{-1}$ ethanol as internal standard. Figure 1 showed a GC chromatogram of a standard solution $\left(6.25 \mathrm{mg} \mathrm{L}^{-1}\right)$.

As it is visible in Table $1 \& 2$, all samples had different amounts of methanol. In qualitative chemical method, the intensity of violet color are shown with,,++++++ and ++++ signs that is equal with 25,50 , 100 and $>100 \mathrm{mg} \mathrm{L}^{-1}$ amounts, respectively. Since, the gained semi quantitative result must multiply to dilution factor (2) for computation of final result, it would be four final semi quantitative answers $(50$, 100,200 and $>200 \mathrm{mg} \mathrm{L}^{-1}$ ) for comparison achieved results by GC method Table $(1 \& 2)$.

\section{Discussion}

Methanol plays an essential role in the land plant physiology, therefore it can be exist in all plant products like juices and herbal distillates that it was confirmed in this study. The most important effective agent on methanol concentration in herbal distillates is related to origin plant tissue used in preparation of product. As, the methanol content in products prepared from green leaves and stem is more than the ones obtained from no green sections of plant (such as flower). This fact is easily visible in achieved results, because, the less mean value $\left(79 \mathrm{mg} \mathrm{L}^{-1}\right.$ ) of methanol existed in Rosa damascena $L$., (that is prepared from flower) with minimum and maximum contents in $\mathrm{A}$ and $\mathrm{B}$ companies samples, respectively. Whereas, the most average (300 $\left.\mathrm{mg} \mathrm{L}^{-1}\right)$ of it was seen in Alhagi maurorum L., (prepared from leaves and green stems) with minimum and maximum contents in B and $\mathrm{C}$ companies samples. Of course, it must be mentioned that since methanol is always producing and storing in plants as an important physiologic compound at different steps of life, its presence in herbal distillates can be deduced as a parameter for proving the authenticity of the product. However, decreasing of its amount in these products is an aid. Also, the comparison of achieved results by both of used methods showed the closeness and similarity of them together (Table $3)$.

Table I The results of chemical method

\begin{tabular}{|c|c|c|c|c|}
\hline Company & $\mathbf{x}$ & $\mathbf{Y}$ & $\mathbf{Z}$ & Average \\
\hline Sample & ---- & ---- & ---- & ---- \\
\hline Mentha Spicata $L$. & $+++(200)$ & $+++(200)$ & $+++(200)$ & $+++(200)$ \\
\hline Foeniculum vulgare $L$. & $++(100)$ & $++(100)$ & $++(100)$ & $++(100)$ \\
\hline Alhagi maurorum $L$. & $++++(>200)$ & $++++(>200)$ & $++++(>200)$ & $++++(>200)$ \\
\hline Anethum graveolens $L$. & $+++(200)$ & $+++(200)$ & $+++(200)$ & $+++(200)$ \\
\hline Cichorium intybus $L$. & $++++(>200)$ & $++++(>200)$ & $++++(>200)$ & $++++(>200)$ \\
\hline Salix aegyptica $L$. & $+++(200)$ & $+++(200)$ & $+++(200)$ & $+++(200)$ \\
\hline Citrus aurantium $L$. & $+++(200)$ & $+++(200)$ & $+++(200)$ & $+++(200)$ \\
\hline Fumaria officinalis $L$. & $+++(200)$ & $+++(200)$ & $+++(200)$ & $+++(200)$ \\
\hline Rosa damascena $L$. & $+(50)$ & $+(50)$ & $+(50)$ & $+(50)$ \\
\hline Trigonella foenum-graecum $L$. & $++++(>200)$ & $++++(>200)$ & $++++(>200)$ & $++++(>200)$ \\
\hline
\end{tabular}

Note: The qualitative results were shown by + and - signs, whereas, the semi quantitative ones were shown based on $\mathrm{mg} \mathrm{L}^{-1}$.

Table 2 The results of $G C$ method (based on $\mathrm{mg} \mathrm{L}^{-1}$ )

\begin{tabular}{|c|c|c|c|c|}
\hline Company & $\mathbf{x}$ & $\mathbf{Y}$ & $\mathbf{Z}$ & Average \\
\hline Name of herbal distillate & ---- & ---- & ---- & --- \\
\hline Mentha Spicata L. & 173 & 203 & 180 & 185 \\
\hline Foeniculum vulgare $L$. & 103 & 120 & 100 & 108 \\
\hline Alhagi maurorum $L$. & 299 & 291 & 310 & 300 \\
\hline Anethum graveolens $L$. & 184 & 243 & 195 & 207 \\
\hline Cichorium intybus $L$. & 233 & 353 & 249 & 278 \\
\hline Salix aegyptica $L$. & 161 & 218 & 202 & 194 \\
\hline Citrus aurantium $L$. & 212 & 175 & 214 & 200 \\
\hline Fumaria officinalis $L$. & 152 & 189 & 176 & 172 \\
\hline Rosa damascena $L$. & 65 & 90 & 81 & 79 \\
\hline Trigonella foenum-graecum $L$. & 224 & 261 & 223 & 236 \\
\hline
\end{tabular}


Table 3 The comparison of the results of two methods

\begin{tabular}{|c|c|c|c|}
\hline Company & Kit Results / mg L'-I & GC Method Results / mg L L & Differences/ $\mathrm{mg} \mathrm{L}^{-1}$ \\
\hline Name of herbal distillate & ---- & ---- & -- \\
\hline Mentha Spicata L. & $+++(200)$ & 185 & 15 \\
\hline Foeniculum vulgare $L$. & $++(100)$ & 108 & 8 \\
\hline Alhagi maurorum $L$. & $++++(>200)$ & 300 & 100 \\
\hline Anethum graveolens $L$. & $+++(200)$ & 207 & 7 \\
\hline Cichorium intybus $L$. & $++++(>200)$ & 278 & 78 \\
\hline Salix aegyptica $L$. & $+++(200)$ & 194 & 6 \\
\hline Citrus aurantium $L$. & $+++(200)$ & 200 & 0 \\
\hline Fumaria officinalis $L$. & $+++(200)$ & 172 & 28 \\
\hline Rosa damascena $L$. & $+(50)$ & 79 & 29 \\
\hline Trigonella foenum-graecum $L$. & $++++(>200)$ & 236 & 36 \\
\hline
\end{tabular}

Generally, the obtained results in this study can be divided into four below categories:

a. There is not any outward difference between attained results by two methods about Citrusaurantium L. sample and they are very similar together $\left(200 \mathrm{mg} \mathrm{L}^{-1}\right)$.

b. In Salix aegyptica L., Anethum graveolens L., Foeniculum vulgare L.andMentha Spicata L. cases, the minimum differences are observable between achieved results by two methods (with 6 , 7,8 and $15 \mathrm{mg} \mathrm{L}^{-1}$ differences, respectively).

c. In Fumaria officinalis L., Rosa damascena L.andTrigonella foenum-graecum $L$. the differences are more than previous ones (with 28, 29 and $36 \mathrm{mg} \mathrm{L}^{-1}$ amounts, respectively).

d. In Alhagi maurorum L.andCichorium intybus $L$. the difference is much more than all previous cases (100 and $78 \mathrm{mg} \mathrm{L}^{-1}$ )

Of course, in comparison of results, it is necessary to mention that the GC method is a fully quantitative technique with very high sensitivity, as, it can easily determine so low amounts (in $\mu \mathrm{g} \mathrm{L}^{-1}$ range) of methanol in samples. However, such high sensitivity is not practically applicable for determination of methanol in herbal distillates industry. Because, as it previously explained, all kinds of herbal distillates always have different amounts of methanol (usually more than $100 \mathrm{mg} \mathrm{L}^{-1}$ ), so, detection or determination of low amount (in $\mu \mathrm{g} \mathrm{L}^{-1}$ range) of it in such products is essentially seemed meaningless. While, the used qualitative chemical method in this study has more less sensitivity (in $\mathrm{mg} \mathrm{L}^{-1}$ range) for semi determination of methanol that from this point of view, it is practically useful to apply for this purpose. Also, the proposed chemical method has several limitations. For example, the operator eyes limitation in color recognition is very important limiting factor in defining of relative methanol content. Therefore, it is deductible, in some cases (C) the two methods results are not completely conform together. However, it can be expected, application of this method in during of time is lead to increase of experience of operator for better recognition of violet intensities and consequently promotion of results quality.

Also, the other significant limiting factor in the proposed chemical method is small range of standard $\left(0->100 \mathrm{mg} \mathrm{L}^{-1}\right)$ that is caused, the final computed result to be limited in $0->200 \mathrm{mg} \mathrm{L}^{-1}$. Therefore, all samples with every amounts of methanol more than $>100 \mathrm{mg}$ $\mathrm{L}^{-1}$ should be shown with ++++ sign (with $>100 \mathrm{mg} \mathrm{L}^{-1}$ value) and consequently $>200 \mathrm{mg} \mathrm{L}^{-1}$ as estimated methanol content. However, to apply a dilution of sample with more than 1:1 ratio (for example, $1: 4)$ and re-examination of it is lead to decrease of violet intensity and consequently promotion of result quality toward fact amount.

As for above explanations and the confirmed need of numerous small producers of herbal distillates in Iran (more than 4000 traditional and industrial unites) that the most of them have not adequate financial abilities and technical knowledge to prepare and apply high technical laboratory equipment for determination of methanol, it seems, the used chemical method in this study can be applied as an inexpensive and suitable alternative tool for easy quality control of these products.

\section{Conclusion}

As it seems, the introduced chemical method is an easy method with suitable sensitivity and accuracy for detection and semi determination of methanol content in herbal distillates and hence, it can be useful to prevention of methanol chronic poisoning and decreasing of its side effects by methanol quality control of methanol in herbal distillates produced by small workshops or companies with no suitable laboratory equipment, high professional knowledge or adequate financial ability.

\section{Acknowledgments}

None.

\section{Conflicts of Interset}

None.

\section{References}

1. Chen SH, Wu HL, Yen $\mathrm{CH}$, et al. Trace determination of methanol in water-ethanol solution by derivation and high-performance liquid chromatography. J Chromatogr A. 2001;799(1-2):93-99.

2. Rafizadeh A, NasiriFard R, Nasoori Gazni M, et al. The effectiveness of whole Concentration of homemade herbal distillates on the result of qualitative methanol detection by the chromotropic acid method. J Ornamental and Horticultural Plants. 2013;3(2):105-109.

3. Rafizadeh A, Pourmohammad L, Shariati Sh, et al. Introducing a Colorimetric Method for the Detection of Methanol in Several Types of Drinks. Journal of Mazandaran University of Medical Sciences. 2011;21(84):150-152.

4. Niinemets U, Reichstein M. Controls on the emission of plant volatiles through stomata: Differential sensitivity of emission rates to stomatal closure explain. Journal of Geophysical Research Atmospheres. 2003a;108(D7).

5. Niinemets U, Reichstein M. Controls on the emission of plant volatiles through stomata: A sensitivity analysis. Journal of Geophysical Research Atmospheres. 2003b;108(D7).

6. Niinemets U, Loreto F, Reichstein M. Physiological and physicochemical controls on foliar volatile organic compound emissions. Trends Plant. 2004;Sci9(4):180-186.

7. Von Dahl C, Havecker M, Schlogl R, et al. Caterpillar-elicited methanol emission: a new signal in plant-herbivore interactions? Plant $J$. 2006;46(6):948-960.

8. Wu MC, Jiang CM, Ho YY, et al. Convenient quantification of methanol in juices by methanol oxidase in combination with basic fuchin. Food Chemistry. 2006;100(1):412-418. 
9. De Gouw JA, Howard CJ, Custer TG, et al. Emissions of volatile organic compounds from cut grass and clover are enhanced during the drying process. Geophysical Research Letters. 1999;26(7):811-814.

10. Frenkel C, Peters JS, Tieman DM,et al. Pectin methylesterase regulates methanol and ethanol accumulation in ripening tomato (lycopersicon esculentum) fruit. J Biol Chem. 1999;273(8):4293-4295.

11. Galbally IE, Kirstine W. The Production of Methanol by Flowering Plants and the Global Cycle of Methanol. Journal of Atmospheric Chemistry. 1998;43(3):195-229.

12. Karl T, Harren F, Warneke C, et al. Senescing grass crops as regional sources of reactive volatile organic compounds. Journal of Geophysical Research. 2005;110(D15):1-11.

13. Loreto F, Barta C, Brilli F, Nogues I. On the induction of volatile organic compounds emissions by plants as consequence of wounding or fluctuations of light and temperature. Plant Cell Environ. 2006;29(9):1820-1828.

14. Holzinger R, Warneke C, Jordan A, et al. Biomass Burning as a Source of Formaldehyde, Acetaldehyde, Methanol, Acetone, Acetonitrile and Hydrogen Cyanide. Geophysical Research Letters. 1999;26(8):11611164.

15. Nemecek-Marshall M, MacDonald RC, Franzen JJ, et al. Methanol emission from leaves: enzymatic detection of gas-phase methanol and relation of methanol fluxes to stomata conductance and leaf development. Plant Physiol. 1995;108(4):1359-1368.

16. Fall R, Benson AA. Leaf methanol - the simplest natural product from plants. Trends in Plant Science. 1998;1(9):296-301.

17. Schulting FL, Meyer GM, Aalst RM. Emissie van koolwaterstoffen door vegetatie en de bijdrage aan de luchtverontreiniging in Nederland. Rapport CMP 80/16 AER 73. 1980.

18. Isidorov VA, Zenkevich IG, Ioffe BV. Volatile organic compounds in the atmosphere of forests. Atmospheric Environment. 1985;19(1):1-8.

19. MacDonald RC, Fall R. Detection of substantial emission of methanol from plants to the atmosphere. Atmospheric Environment. Part A General Topics. 1993;27A(11):1709-1713.

20. Karl T, Spirig C, Rinne J, et al. Virtual disjunct eddy covariance measurements of organic compound fluxes from a subalpine forest using proton transfer reaction mass spectrometry. Atmospheric Chemistry and Physics. 2002;2:279-291.

21. https://www.nap.edu.

22. Belson M, Morgan BW. Methanol toxicity in a newborn. J Toxicol Clin Toxico. 2004; 42(5): 673-677.

23. Salek T, Humpolicek P, Ponizil P. Metabolic disorders due to methanol poisoning. Biomed Pap Med Fac Univ Palacky Olomouc Czech Repub. 2004;158(4):635-639.

24. Shahriari HA, Hosseini Rad A. preventive effects of vitamin B12 and folic acid in methanol-induced retinopathy in an animal model. Medical Journal of the Islamic Republic of Iran. 2000;4(1):83-86.

25. Paasma R, Hovda KE, Hassanian-Moghaddam H. Risk factors related to poor outcome after methanol poisoning and the relation between outcome and antidotes -a multicenter study. Clinical Toxicology. 2012.

26. Brent J. Fomepizole for Ethylene Glycol and Methanol Poisoning. $N$ Engl J Med. 2003;360(21):2216-2223.

27. Moghadami M, Masoumpoor M, Tabei SMB, et al. Therapeutic Response to Folinic Acid in Methanol Poisoning Epidemic in Shiraz. IJMS. 2008.

28. Shams Vahdati S, Rajaei Ghafouri R, Dalil S, et al. Alcohol Poisoning in Toxicology Center of East Azarbaijan Province of Iran. Eurasian Journal of Emergency Medicine, 2015. p. 131-133.
29. Shadnia Sh, Rahimi M, Soltaninejad K, et al. Role of clinical and paraclinical manifestations of methanol poisoning in outcome prediction. $J$ Res Med Sci. 2013;18(10):865-869.

30. Kostik V, Gjorgeska B, Angelovska B, et al. Determination of some volatile compounds in fruit spirits produced from grapes (Vitis Vinifera L.) and plums (Prunus domestica L.) cultivars. Science Journal of Analytical Chemistry. 2014;2(4):41-46.

31. Sanaeizadeh H, Emamhadi MA, Farajidana H, et al. Electrocardiographic manifestations in acute methanol poisoning cannot predict mortality. Arh Hig Rada Toksikol. 2013;64(2):79-85.

32. Brent J, Mcmartin K, Hillips SP, et al. Fompizole for the treatment of methanol poisoning. The New England Journal of Medicine. 2001.

33. Pajoumand AK. Prognostic Factors Including Clinical manifestation and Para clinic finding in Sever Methanol Toxicity. Alcoholism \& Drug Dependence. 2013.

34. McMartin K, Jacobsen D, Hovda KE. Antidotes for poisoning by alcohols that form toxic metabolites. Br J Clin Pharmacol. 2015;81(3):505-515.

35. Karimi Gh, Hassanzadeh M, Shahihdi N. Determination of methanol in Mashhad produced distillated herbaceous by spectrophotometric method. Faslnameh giahan daroee. 2007;1(7):57-59.

36. Solhi H, Delavar M, Cheshme Jahanbin A, et al. Comparison of methanol concentration in herbal essences produced in Arak city with industrial produced herbal essences with different commercial brands. Arak Medical University Journal. 2008;12(3):85-91.

37. Rafizadeh A, Shariati Sh, Safarzadeh Vishekaei MN. Determination of herbal distillates methanol with a special diagnostic kit. Journal of Guilan University of Medical Sciences. 2015;24(96):61-67.

38. Quanmin L, Huanhuan Z. Study of methanol catalyzed reaction between sodium 1, 2- aphthoquine-4-sulfonate and hydroxyl on and its application in the determination of methanol. $J$ Spectrochim Acta. 2008;71:245-251

39. Ashraf AM, Ahmed TM, Zakaria MHM, et al. Highly sensitive and selective catalytic determination of formaldehyde and acetaldehyde. Talanta. 2008;74(4):578-585.

40. Garcia de Maria C, Manzano T, Duarte R, et al. Selective flow-injection determination of methanol using immobilized enzyme reactors. Analytical Chimica Acta. 2008;309(1-3):241-250.

41. Perez-Ponce A, Rambla FJ, Garrigues JM, et al. Simultaneous vapour phase Fourier transform infrared spectrometric determination of butyl acetate, toluene and methyl ethyl ketone in paint solvents. Analyst. 1998;123:1247-1252.

42. Savary BJ, Nuñez A. Gas chromatography-mass spectrometry method for determining the methanol and acetic acid contents of pectin using headspace solid-phase micro extraction and stable isotope dilution. $J$ Chromatogr. 2003;A1017(1-2):151-159.

43. https://www.cdc.gov/niosh/docs/2003-154/pdfs/3500.pdf

44. Sritharathikhun P, Oshima M, Motomizu S. On-line collection concentration of trace amounts of formaldehyde in air with chromate membrane cell and its sensitive determination by flow injection technique coupled with spectrophotometric and fluorometric detection. Talanta. 2005;67:1014-1022.

45. Motyka K, Mikuska P. Continuous fluorescence determination of formaldehyde in air. Analytica Chimica Acta. 2004;518(1-2):51-57.

46. Pinheiro HLC, de-Andrade MV, de-Paula-Pereira PA, et al. Spectrofluorimetric determination of formaldehyde in air after collection onto silica cartridges coated with Fluoral P. Microchemical Journal. 2008;78(1):15-20. 
47. Song Z, Hou S. On-line monitoring of formaldehyde in water and air using chemiluminescence detection. International Journal of Environmental Analytical Chemistry. 2003;83(9):807-817.

48. Fagnani E, Melios CB, Pezza L, et al. Chromotropic acid formaldehyde reaction in strongly acidic media. The role of dissolved oxygen and replacement of concentrated sulfuric acid. Talanta. 2003; 60(1):171176.
49. Horwitz W, Latimer GW. Association of Official Analytical Chemists. Official Methods of Analysis of AOAC International. Gaithersburg MD (Rds.), (18th edn), AOAC International, 2006. p. 15-16.

50. Wang ML, Wang JT, Choong YM. A rapid and accurate method for determination of methanol in alcoholic beverage by direct injection capillary gas chromatography. Journal of Food Composition and Analysis. 2004;17(2):187-196. 